\title{
DORIS ZEMURRAY STONE
}

$$
\text { 1909-1994 }
$$

The death of Doris Stone' shortly before her 85th birthday, on October 21, 1994, marks the end of an era in Central American anthropology. Her interest in the archaeology and ethnology of Honduras began in the 1920s, and her contributions continued unabated until the end of her life. She is best known for her pioneering studies in the archaeology of Honduras and Costa Rica and for her comprehensive, synthetic volumes on prehispanic Central America, but she also published extensively on the ethnography and ethnohistory of indigenous Central American peoples. Doris devoted much effort to the welfare of the indigenous peoples and to the development of local archaeology and museum facilities in Costa Rica, and the extent and diversity of current archaeological research in that country owe much to her efforts.

Doris Zemurray Stone was born in New Orleans, Louisiana, on November 19,1909, the daughter of Samuel and Sarah Weinberger Zemurray. Her father was a successful U.S. businessman with ties to Honduras and other countries in Central America. She spent her childhood in New Orleans, in Bay St. Louis, Mississippi, and later at her family's country estate north of Hammond, Louisiana. She traveled regularly to Honduras, Costa Rica, and Guatemala, and was captivated early on by the land, the people, and the archaeology.

She attended Newman School in New Orleans and in 1926 enrolled at Radcliffe College, where she majored in anthropology, graduating in 1930. She took two graduate archaeology courses, but wrote that "In the 1920 s I was required to obtain permission from the president of Harvard to attend classes at the Peabody Museum, and with the permission came the warning that if my deportment was not entirely proper, my association with that austere building would be ended" (1980:20).

While at Radcliffe, Doris met Roger Thayer Stone, a graduate student in physics at Harvard, and on November 22, 1930, they were married. For the next decade Doris and Ronnie lived in New Orleans. They moved to San José, Costa Rica, in 1939, settling on a coffee plantation in Curridabat after World War II. Except for a year spent in Santiago, Chile, during the war, this was their home until Ronnie retired. In 1962, they returned to Louisiana, building a home on the Tchefuncte River, in Madisonville, where they remained for the rest of their lives.

${ }^{1}$ We are grateful to Samuel Zemurray Stone for help in preparing this obituary and for the accompanying photographs.

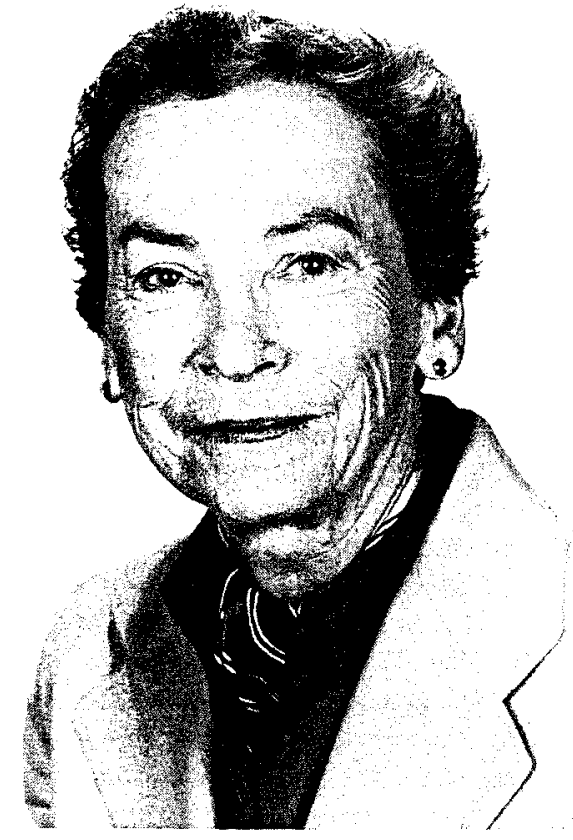

Doris Zemurray Stone in 1981. Photo by Mike Posey. (Courtesy of Middle American Research Institute, Tulane University.)

When Doris became interested in the anthropology of Central America, little was known about either the archaeology or the ethnography of most of this region. Many areas of Honduras and Costa Rica were lightly occupied and poorly known, and travel was difficult and slow. Her most important scholarly contributions were to the archaeology of Honduras. She excavated a number of buildings at the important site of Travesía, beside the Ulúa River, in 1936 and 1937 (1941a) but undertook few other excavations; her greatest efforts were given to an archaeological survey of nearly the entire country published in Archaeology of the North Coast of Honduras (1941a), The Archaeology of Central and Southern Honduras (1957), and a long series of articles (e.g., 1940, 1942, 1948a, 1959, 1967, 1968). In these two Peabody Museum volumes, Doris described more than 80 archaeological sites, including many of the largest in the country, and many artifacts, most often pottery, found at each. For 


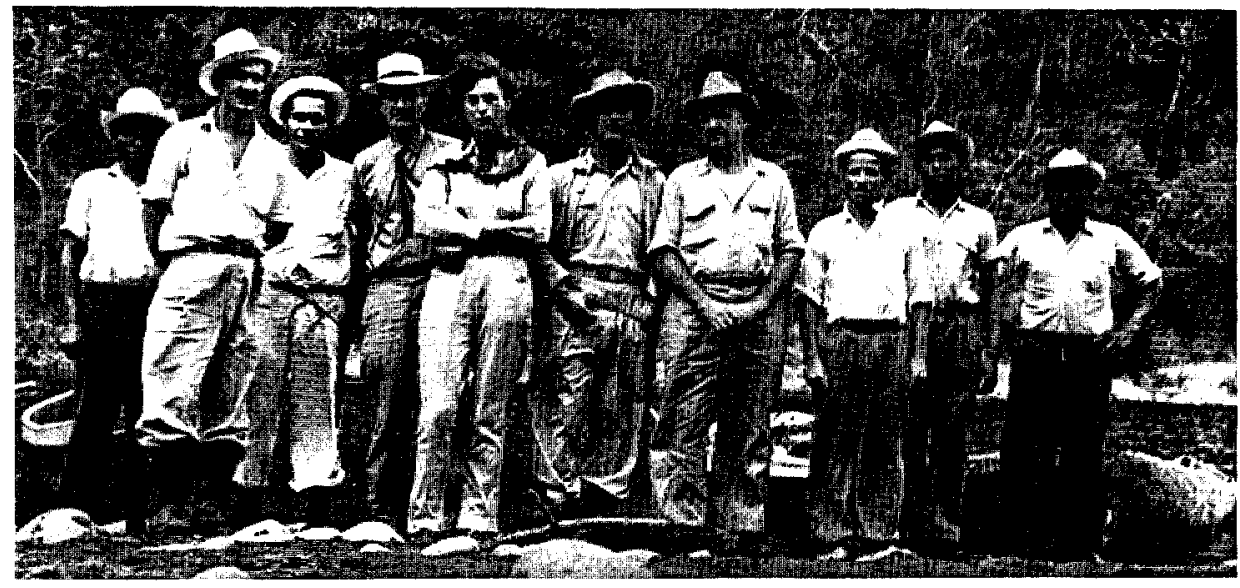

Doris Stone stands just to the right and in front of Roger Thayer Stone on the bank of the Rio Grande de Térraba (Diquis) in southern Costa Rica in the mid-1940s. some of the larger indigenous groups, she prepared short ethnographies.

In each profusely illustrated volume she defined geographic subregions that were characterized by artifact complexes, or at least by general similarities of material, especially decorative styles on pottery vessels. She summarized what was known about the culture and history of each region while confronting the difficulties posed by the absence of any stratigraphic archaeology or other reliable dating methods. Turning then to what information was available from ethnohistoric, linguistic, and modern ethnographic accounts, she attempted to link these archaeologically defined areas with linguistic and ethnic groups and to determine their relationships to cultures in Mesoamerica and in southern Central America and South America.

This problem orientation and Doris's overall method of research in Central America were supported by Alfred Tozzer, who wrote in his foreword to her north coast study, "There is no more important problem in the entire Maya field than the establishment of its southern frontier and a knowledge of its relationships with the cultures lying to the southward" (194la:v).

Doris believed that Honduras was divided into three major archaeological areas and one smaller buffer region. To the west was the Ulúa drainage, with strong Maya and central Mexican ties; on the north and northeast was the Caribbean side, with South American-related Chibchan groups, most notably the Paya; and the third was a central and southwestern highland area, identified with the Lenca, who showed strong South American links as well as ties with Mexico and Guatemala. Between and bordering these three was the Sula-Jicaque buffer group, defined primarily by language as the zone was difficult to isolate using archaeological markers. Doris recognized the extent to which Central America was a melting pot of ancient cultures from north and south (1940, 1941 b, 1967, 1968, 1972, 1977), but she also argued $(1948 \mathrm{a}, 1957)$ that there was a relatively unmixed complex that was native to Central America but essentially South American in ethnographic and archaeological features.

The identification of ancient remains with modern ethnic groups is not often a primary goal today. In Honduras a half century ago, however, little was known of the ancient inhabitants and their history, and this approach was a way to focus all obtainable anthropological information on the study of culture history. To this end Doris read ethnohistorical sources (1932, 1941c) and studied the Lenca (1948c) and other indigenous groups of Honduras.

Doris's impact on Costa Rican archaeology and ethnography and on the native inhabitants of that country was also comprehensive and permanent. In 1945, she established the Council for the Protection of Indigenous Races, spearheading the movement to assist and educate the rapidly dwindling and heavily affected populations of indigenous peoples of Costa Rica, while helping them maintain their cultural integrity (1948b, 1949b). Many of them came to love and respect her.

In 1948, after the Costa Rican Revolution led by José (Don Pepe) Figueres Ferrer, she persuaded Figueres to allow her and other museum board members to convert the Bellavista Fortress, a central location in the 1948 revolution, into the National Museum of Costa Rica. He agreed to let her have the fortress but explained that she would have to wait until he evacuated 3,500 troops and that he had no funds to help her restore the enormous building. With the counsel of friends, she raised the first funds from the Costa Rican Congress through Manuel Mora Valverde, the founding leader of the Communist party and a formidable enemy of her father, the president of the United Fruit Company, and of what he represented. Her efforts helped Don Pepe in his eventual decision to abolish the army. She used volunteered labor and supplies and served for many years as chairman of the museum's board. Upon Figueres's death in 1990, his body lay there in state.

She published the first comprehensive overview of Costa Rican prehistory (1958b) and later wrote two broad syntheses, Pre-Columbian Man Finds Central America: The Archaeological Bridge (1972) and Pre-Columbian Man in Costa Rica (1977). During the years in Costa Rica, she undertook studies on metallurgy $(1958 \mathrm{a})$, jade $(1963,1964,1993)$, plant diffusion (1984b), stone sculpture (1961), aboriginal ceramics, both ancient (1982, 1983) and modern (1951a), and other subjects.

Her 60 years of archaeological publications defined many of the themes that were and often still are important foci of research. Among them were (1) the nature and extent of Mesoamerican influence (although she tended to see more direct diffusion than did many who followed her, her mind remained open to new data, and she participated in the ongoing debate); (2) the tripartite cultural subdivision of Costa Rica that has been the established research framework for more than four decades; (3) an ethnohistorical and ethnoarchaeological approach to 
some archaeological elements, such as southern Costa Rican cult symbols; and (4) the importance of the technological relationship between tool assemblages and subsistence practices, and especially the role of maize in pre-Columbian Costa Rica.

It is a reflection of the breadth and depth of her published research that most licenciatura theses from the University of Costa Rica, most masters theses and doctoral dissertations from North American and European universities, and most scholarly publications dealing with Central America cite her work extensively.

Although she is most widely identified as an archaeologist, especially outside the country, in Costa Rica she is equally remembered for her work with and publications about contemporary indigenous peoples. She made contributions in folklore (1951b, 1951c), ethnohistory (1966), and ethnography (1952, 1956). The research on which her important monographs on the Boruca (1949) and the Talamancan (1962) tribes are based could not be repeated today, because most of these societies no longer exist in their aboriginal form.

She organized and was president of the 33rd International Congress of Americanists, held in San José in 1958 (1959a), and thereafter served as a member of its permanent council. She was especially fond of these congresses, which drew a wide range of scholars from around the world. She frequently, and often anonymously, helped fellow Central American scholars either by commending them to a particular government or institution or providing travel and research support.

Throughout her life she was active in the educational and cultural affairs of the communities in which she lived. From 1942 until 1963 she was president of the board of directors of the Escuela Agrícola Panamericana at Zamorano, near Tegucigalpa, Honduras. This premier agricultural college in Central America, founded by Doris and her father, received her steadfast care and support throughout her life.

In the United States, she was a Research Associate of the Middle American Research Institute at Tulane and a close associate of the Department of Anthropology and the Center for Latin American Studies. She was a research associate and member of the Visiting Committee of the Peabody Museum of Harvard, a trustee of Radcliffe College, and a member of the Board of Visitors and the President's Council at Tulane. She served on the boards of the University of San Pedro Sula, the Academia Costarricense de la Historia, the New Orleans Museum of Art, the New Orleans City Ballet, the New Orleans Opera Association, the Louisiana Nature and Science Center, the Greater New Orleans Regional Foundation, the Audubon Institute of New Orleans, the School of American Research in Santa Fe, the Archaeological Conservancy, and the Museum of the American Indian (Heye Foundation).

The institutions and countries to which she gave her time and support honored her. She received honorary degrees from Tulane University (1957), Union College (1973), and Radcliffe College (1994) and was awarded the Harvard Medal (1993) and the first medal of the International Congress of Americanists (1994). She was a Comendador of the Order of Rubén Dario of Nicaragua and of the Order of Francisco Morazán of Honduras, a Caballero of the Order of Vasco Núñez de Baboa of Panama, a Chevalier of the French Legion of Honor, and an honorary citizen of Honduras.

Doris was an inveterate traveler. When she was young, she went everywhere in Honduras and Costa Rica on horseback, for there were no roads. Her first trip to Copan, in far western Honduras, was on muleback, long before the Carnegie Institution of Washington managed to drive in the first truck.

In the 1920s, she and Emita Bonilla de Larios, a daughter of the president of Honduras, rode on horseback from that country to San Carlos, Costa Rica, across the San Carlos plains (a long ride), and from there, with only a partial bottle of rum and five or so slightly burned tortillas to sustain them, took off across Lake Nicaragua by packet boat for Granada. The night was stormy, and after 6 or 8 hours they arrived in Granada dripping wet at 4 A.M. The Cuadra family of Granada, friends of both the young women's fathers, allowed the girls to dry out in their home. This adventure and others happened at a time when long-distance solo travel in Central America was unheard of for young women. Doris admitted to her son that these travels were often against the wishes of her father.

In the summer of 1928 , after her sophomore year at Radcliffe, she traveled to the Soviet Union, going as far as Finland with Harvard philosopher Thomas Dewey and Senator Robert LaFollette of Wisconsin. Her companions became ill there, but she went on to Moscow by herself (she did speak some Russian, learned from her father). From there she boarded a train that took her to Siberia; she was disguised as a Cossack because women were not allowed to travel alone. Side trips included a boat trip down the Volga and a 4-day horseback trip across the Caucasus Mountains, also with Cossacks and five students from Yale University. Her father in Boston was furious but helpless.

She initiated Ronnie to a peripatetic marriage by arranging a honeymoon that consisted of a 16-day muleback trip from Honduras through El Salvador to Agua Volcano, in Guatemala, as chaperons for a then-unmarried couple. They also traveled widely afterward on horseback across the hills of southern Spain. In her late 70 s and early 80 s, Doris traversed Bolivia, China, India, Kashmir, Nepal, Bhutan, Siberia, Burma, Thailand, Indonesia, and other countries with energy and enthusiasm that left her younger companions exhausted. She died two weeks after her last trip, which was to Ethiopia.

Doris got her hands dirty, did her homework, worked as hard at her publications and professional activities as full-time university and museum professionals, and held high standards for the projects she was involved with. She co-organized the 1980 Advanced Seminar on Lower Central American Archaeology at the School of American Research and co-edited the resulting volume; Lange, her co-editor, remembers the marathon manuscript review session at the Madisonville house, from 11 A.M. until 1:30 the next morning and then from $6: 30$ to $8: 30$ the same morning before he escaped to the airport, with awe and admiration. She never complained about personal discomforts. At the International Congress of Americanists in Manchester, England, in 1982, she completed the morning session, went to lunch, came back and finished the afternoon session, and only then asked to go to the hospital, because since the late morning she was sure she had had a heart attack (and she had)! In the March heat on the Bay of Culebra, at the age of 83, Doris walked around looking at shell middens at the Vidor site while Lange and her friend George Riser were hunting shade.

She loved people, empathizing naturally and genuinely with those around her, from presidents to poor farmers, and people loved her in return. Her joie de vivre never ran out, and she was a delight to be around. Role models and friends like Doris are unique. 
Doris is survived by her son and daughter-in-law, Samuel Zemurray Stone and Haydée Terán Stone; three granddaughters, Haydée María Mendiola Paniagua, Alison Stone Golcher, and Stephanie Stone Foeli; five great-grandchildren; and a nephew, Samuel Zemurray III, the offspring of Doris' younger brother, Samuel Zemurray Jr.

\section{E. Wyllys ANDREWS V} FREDERICK W. LANGE

\section{SELECT BIBLIOGRAPHY OF DORIS Z. STONE²}

1932 Some Spanish Entradas, 1524-1695. In Middle American Papers: Studies Relating to Research in Mexico, the Central American Republics, and the West Indies, pp. 209-296. Publication No. 4, Department of Middle American Research, Tulane University, New Orleans.

1940 The Ulua Valley and Lake Yojoa. In The Maya and Their Neighbors, edited by Clarence L. Hay et al., pp. 386-394. D. AppletonCentury, New York.

194la Archaeology of the North Coast of Honduras. Memoirs of the Peabody Museum of Archaeology and Ethnology, vol. 9, no. 1. Harvard University, Cambridge.

$1941 \mathrm{~b}$ (senior author, with Conchita Turnbull) A Sula-Ulúa Pottery Kiln. American Antiquity 7:39-47.

1941c Una consideración del valor de ciertas fuentes históricas en el estudio de Honduras precolombina e histórica. Ariel, Series 32, 9597:2349-2351, 2378-2379, 2403-2406. San José, Costa Rica.

1942 A Delimitation of the Area and Some of the Archaeology of the Sula-Jicaque Indians of Honduras. American Antiquity 7:376-388.

1948a The Basic Cultures of Central America. In The Circum-Caribbean Tribes, pp. 169-193. Handbook of South American Indians, vol, 4, Julian H. Steward, general editor. Bulletin 143. Smithsonian Institution, Bureau of American Ethnology, Washington, DC.

1948b Indians and Costa Rica. Bulletin of the Pan American Union 82:61-69.

1948c The Northern Highland Tribes: The Lenca. In The CircumCaribbean Tribes, pp. 205-217. Handbook of South American Indians, vol. 4, Julian H. Steward, general editor. Bulletin 143. Smithsonian Institution, Bureau of American Ethnology, Washington, DC.

1949 The Boruca of Costa Rica. Papers of the Peabody Museum of Archaeology and Ethnology, vol. 26, no. 2. Harvard University, Cambridge.

1949b Indian Education on the March. Boletin Indigenista 9:332-337. Mexico, DF. [Spanish and English text]

1951a Notes on Present-Day Pottery Making and Its Economy in the Ancient Chorotegan Area. In Middle American Research Records, vol. 1, pp. 269-280. Publication No. 15. Middle American Research Institute, Tulane University, New Orleans.

1951b A Report on Folklore Research in Costa Rica. Journal of American Folklore 64:97-103.

1951c A Report on Folklore Research in Honduras. Journal of American Folklore 64:113-120.

\footnotetext{
${ }^{2}$ Stephen Williams compiled a list of 156 items, including 13 books and monographs, in his "Bibliography of Doris Stone: Her Works From 1930 to 1984," in Research and Reflections in Archaeology and History: Essays in Honor of Doris Stone (1986, pp. 203-209, edited by E. Wyllys Andrews V, Middle American Research Institute Publication No. 57, Tulane University, New Orleans). The list of references here includes Doris Stone's four publications since 1984. Additional biographical information may be found in "Doris Stone: The Pathways of a Middle American Scholar," also by Stephen Williams, on pages 199-202 of the above volume; in "Doris and the Indians: U.S. Woman Heads Program Bringing Civilization to the Costa Rican Tribes," By Joaquin Vargas Coto (1953, Americas 5(1):9-11, 29, Washington, DC); and in "A Fair Period for a Field Study" (1980), a speech Doris gave at her 50th Radcliffe reunion. She penned a few comments about her own pioneering work in "A History of Lower Central American Archaeology" (1984a).
}

1952 Living Archaeology of the Bribri and Cabecar Indians of Costa Rica. In Indian Tribes of Aboriginal America. Selected Papers of the XXIX International Congress of Americanists (Chicago, 1952), vol. 3, edited by Sol Tax, pp. 251-253. University of Chicago Press, Chicago.

1956 Breve esbozo etnológico de los pueblos indígenas costarricenses. In Estudios antropológicos publicados en homenaje al doctor Manuel Gamio, pp. 503-511. Universidad Nacional Autónoma de México, Mexico, DF.

1957 The Archaeology of Central and Southern Honduras. Papers of the Peabody Museum of Archaeology and Ethnology, vol. 49, no. 3. Harvard University, Cambridge.

1958a The Aboriginal Metalwork in the Isthmian Region of America. Museo Nacional, San José, Costa Rica.

1958b Introduction to the Archaeology of Costa Rica. Museo Nacional, San José, Costa Rica.

1959a (editor) Actas del XXXIII Congreso Internacional de Americanistas (San José, 1958). 3 vols. Lehmann, San José.

1959b The Eastern Frontier of Mesoamerica. In Amerikanische Miszellen: Festband Franz Termer, edited by W. Bierhenke et al., pp. 118121. Mitteilungen aus dem Museum für Völkerkunde in Hamburg, vol. 25. Hamburg.

1961 The Stone Sculpture of Costa Rica. In Essays in Pre-Columbian Art and Archaeology, edited by Samuel K. Lothrop et al., pp. 192209. Harvard University Press, Cambridge.

1962 The Talamancan Tribes of Costa Rica. Papers of the Peabody Museum of Archaeology and Ethnology, vol. 43, no. 2. Harvard University, Cambridge.

1963 Cult Traits in Southeastern Costa Rica and Their Significance. American Antiquity 28:339-359.

1964 Arte precolombino de Costa Rica con 20 reproducciones en color de la colección del Museo Nacional. Museo Nacional, San José, Costa Rica.

1966 Synthesis of Lower Central American Ethnohistory. In Archueological Frontiers and External Connections, edited by Gordon F. Ekholm and Gordon R. Willey, pp. 209-233. Handbook of Middle American Indians, vol. 4. Robert Wauchope, general editor. University of Texas Press, Austin.

1967 The Significance of Certain Styles of Ulua Polychrome Ware From Honduras. Folk: Dansk Etnografisk Tidsskrift 8-9:335-342. Copenhagen.

1968 An Interpretation of Ulua Polychrome Ware. Verhandlungen des XXXVIII. Internationalen Amerikanistenkongresses (StuttgartMunich 1968) 2:67-76. Munich.

1972 Pre-Columbian Man Finds Central America: The Archaeological Bridge. Peabody Museum Press, Harvard University, Cambridge.

1977 Pre-Columbian Man in Costa Rica. Peabody Museum Press, Harvard University, Cambridge.

1980 A Fair Period for a Field Study. Radcliffe Quarterly 66(3):20-22. 1982 Cultural Radiations from the Central and Southern Highlands of Mexico into Costa Rica. In Aspects of the Mixteca-Puebla Style and Mixtec and Central Mexican Culture in Southern Mesoamerica, organized by Doris Stone, pp. 61-70. Occasional Paper 4. Middle American Research Institute, Tulane University, New Orleans.

1983 Synthesis of Pre-Columbian Ceramics from Costa Rica. Indiana 8:201-221. Berlin.

1984a A History of Lower Central American Archaeology. In The Archaeology of Lower Central America, edited by Frederick W. Lange and Doris Z. Stone, pp. 12-32. A School of American Research Book. University of New Mexico Press, Albuquerque.

1984b Pre-Columbian Migration of Theobroma cacao Linnaeus and Manihot esculenta Crantz from Northern South America into Mesoamerica: A Partially Hypothetical View. In Pre-Columbian Plant Migration, edited by Doris Z. Stone, pp. 67-83. Papers of the Peabody Museum of Archaeology and Ethnology, vol. 76. Harvard University, Cambridge.

1985a Archaeological Work in Costa Rica. In Art of Costa Rica: Pre-Columbian Painted and Sculpted Ceramics from the Arthur $M$. Sackler Collections, edited by Lois Katz, pp. 211-214. The Arthur M. Sackler Foundation and the AMS Foundation for the Arts, Sciences and Humanities, Washington, DC.

1985b Pre-Columbian Trade in Costa Rica. In Art of Costa Rica: Pre-Columbian Painted and Sculpted Ceramics from the Arthur. $M$. 
Suckler Collections, edited by Lois Katz, pp. 215-237. The Arthur M. Sackler Foundation and the AMS Foundation for the Arts, Sciences and Humanities, Washington, DC.

1986 (translated and annotated by) Report Made in the Royal Council of the Indies on the Pacification and Population of the Provinces of the Manche and Lacandon, etc. With additional notes by Frank $\mathrm{E}$. Comparato, editor. Labyrinthos, Culver City, California. Originally published 1932 as Some Spanish Entradas, 1524-1695. In Middle American Papers, pp. 209-296. Publication No. 4. Department of Middle American Research, Tulane University, New Orleans.

1993 Jade and Jade Objects in Precolumbian Costa Rica. In Precolumbian Jade: New Geological and Cultural Interpretations, edited by Frederick W. Lange, pp. 141-148. University of Utah Press, Salt Lake City. 